\title{
Voting Yourself a Farm in Antebellum Iowa
}

\section{Towards an Urban, Working-class Prehistory of the Post-Civil War Agrarian Insurgency}

\section{MARK A. LAUSE}

Peculiar Rituals transpired in the woods of Iowa in the early 1850s. Robed men gathered at night to hear an even more ornately disguised Herald introduce "the enemies of Mankind." Drawing a curtain, he revealed a "table covered with scarlet, on which a dim taper is burning. Beside the taper appear a skull, a goblet filled with red liquid, a copy of the Declaration [of American Independence], the Gospel of N[azareth] and a Map of the Continent of America." Around it, like the witches in Macbeth, cavorted three "Lords of Labor" who drank the symbolic blood, boasted of their ability to distill labor into gold and paper money, cursed the Declaration and the Gospel, and discussed the progress of their conquest over the New as well as the Old World. Then, a "Chief Washington" made a circle around the initiates, pledging them the protection of the order, and an "Exalted Washington" appeared "in the garments of poverty and labor." Recalling the old biblical parable of the rods, officers demonstrated how easily one alone is broken, and they applied the lesson both to the union of the American states and to the potential strength of the "solitary Son of Labor" when united with peers. Finally, they showed "the grip, sign and passwords" of a secret society of radicals active throughout the state and the nation with ties to the developing revolutionary movement in Europe. ${ }^{1}$

1. The rites of initiation described here are from the Brotherhood of the Union's secret ritual book known only as the B.G.C. (Philadelphia, [1850?]), $36,44,48,51,58$. A copy exists in the archives of the Brotherhood of America, Historical Society of Pennsylvania, Philadelphia. 
These self-decribed "Agrarians" celebrated values that clearly presaged concerns associated with the post-Civil War agrarian insurgency of the Greenbackers, Anti-Monopolists, and Populists, and their presence in the antebellum upper Midwest suggests new insights into the roots of that broad discontent that erupted so dramatically a generation later.

The postwar agrarian revolt has attracted increasing attention from scholars over the years. Historians have explored its sources in immediate grievances and currency reform while describing its deeper origins in a broad popular resistance to the transformation of American life by the developing economic, social, and political dominance of corporate capitalism. More neglected, however, has been the line of inquiry suggested by Chester A. Destler, that the discontent expressed by Greenbackers and Populists had grown from an earlier radicalism expressed in labor circles of the eastern cities. ${ }^{2}$

A great deal of further research may be needed to appreciate the full significance of those disguised Iowans in the 1850s, but their early activities clearly constituted an earlier radical Agrarian experience that was both local and antebellum. For decades before the Civil War eastern working-class people persistently suggested that the health of American democracy required the landless citizen to "Vote Yourself a Farm." Such ideas and values found adherents among individuals and organizations in antebellum Iowa, one of the key areas in the upheaval of a generation later. Their presence suggests a neglected continuity in Agrarian radicalism over these decades.

2. Older works of interest include Norman Pollack, The Populist Response to Industrial America: Midwestern Populist Thought, 2d ed. (New York, 1966); typical of more recent scholarship are Lawrence Goodwyn, Democratic Promise: The Populist Movement in America (New York, 1976), published in a slightly abbreviated form as The Populist Moment: A Short History of the Agrarian Revolt in America (New York, 1978), and Robert C. McMath, Jr., Populist Vanguard: A History of the Southern Farmers' Alliance, 2d ed. (New York, 1977). Also, of course, see Chester McArthur Destler, American Radicalism, 18651901, 2d ed. (Chicago, 1966). No modern study of the Greenback-Labor insurgency of the 1870 s exists, although it made a stronger national showing in the off-year election of 1878 than the later Populists did in the 1890 s. See Fred E. Haynes, Third Party Movements Since the Civil War, with Special Reference to Iowa: A Study in Social Politics, 2d ed. (New York, 1966). 
$I_{N} 1844$, almost a half-century before the heyday of the Populists, a handful of New York City radicals organized an Agrarian League which became known officially as the National Reform Association (NRA). It may seem ironic that these eastern, urban, working-class people formulated and labeled their ideological persuasion as "Agrarianism," which has since assumed exclusively rural implications. However, their use of the term originated in their plebeian acceptance of the patrician practice of discussing American politics in the terms of classical republican experience. The New York City working-class people who founded the Agrarian League sought to apply their own interpretation of ancient Roman "Agrarian Law," the policy promoted by the Gracchi brothers of encouraging widespread land holding among citizens. In the burgeoning young American republic, no less a figure than Thomas Paine had argued that propertyless and landless people enjoyed less in a state of civilization than in a state of nature and that, consequently, civilized society owed them some form of compensation. In 1829 Thomas Skidmore, a Yankee-born theorist and labor organizer, appropriated this legacy of ideas that mandated an egalitarian democracy with social and economic dimensions, and used the term Agrarian to describe his call for a new American revolution aimed at the expropriation of great fortunes and their redistribution in various forms to the people. ${ }^{3}$

Founders of the NRA included men like George Henry Evans, a veteran of these earlier experiences. The principal theorist and organizer of the new movement, Evans had worked with Skidmore in the local Workingmen's party in 1829, and, after the final demise of the party, he helped to lead New York's antimonopolist, "Loco-Foco" revolt of 1836 against the local Democratic leadership in the city. Driven by poor health and

3. Thomas Paine sketched his argument in his Rights of Man, Part Second (1792) and Agrarian Justice (1796); see also Mark A. Lause, "The 'Unwashed Infidelity': Thomas Paine and Early New York City Labor History," Labor History 27 (Summer 1986), 385-409. For Skidmore, see Walter Hugins, Jacksonian Democracy and the Working Class: A Study of the New York Workingmen's Movement, 1829-1837 (Stanford, Calif., 1960), 82-84; Edward Pessen, Most Uncommon Jacksonians: The Radical Leaders of the Early Labor Movement (Albany, N.Y., 1967), 58-66; and the original biographical essay of 1834 by Amos Gilbert published as The Life of Thomas Skidmore, ed. Mark A. Lause (Chicago, 1984). 
poverty to a small farm in New Jersey, he spent several years formulating a more practical and popular means of moving American society towards an Agrarian destiny. Returning to the city in the winter of 1843-44, he began what he hoped would become a truly national movement with a handful of his peers meeting in the back room of John Windt's Manhattan print shop. ${ }^{4}$

The NRA articulated a coherently Agrarian critique of American society. ${ }^{5}$ Natural law, it insisted, required an institutionalized respect for human equality attainable only by insuring each citizen an equal voice in government. Such a genuine democracy required a level of economic and social equality unrealized in any modern society, including the United States; the New World's acceptance of the hierarchial economic order of the Old World, based largely on landed wealth, threatened to subvert the nation's democratic potential. Citing the seemingly endless expanse of unsettled land and the absence of a titled nobility, the NRA called for a uniquely American solution based on a popular movement to achieve three "transitional measures": homestead exemption, the security of the family farm against

4. On the scope of the local Workingmen's parties, see Alden Whitman, Labor Parties, 1827-1834 (New York, 1943), 63. For scholarly appraisals of these early labor movements, see Hugins, Jacksonian Democracy; Pessen, Most Uncommon Jacksonians; Philip S. Foner, History of the Labor Movement in the United States, vol. 1, From Colonial Times to the Founding of the American Federation of Labor, 2d ed. (New York, 1972); and Sean Wilentz, Chants Democratic: New York City and the Rise of the American Working Class, 1780-1850 (New York, 1984). The best single source on the National Reform Association remains Helene Sara Zahler, Eastern Workingmen and National Land Policy, 1829-1862 (New York, 1941), and, on its principal theorist, James Stanford Bradshaw, "George Henry Evans," in Perry J. Ashley, ed., American Newspaper Journalists, 1690-1872, vol. 43 of Dictionary of Literary Biography (Detroit, 1985), 184-88.

5. The best sources on Agrarian ideology are Evans's newspapers, the Workingman's Advocate of 1844-1845, and its successor, Young America, or, more accessibly, the relevant pieces in John R. Commons et al., eds., $A$ Documentary History of American Industrial Society, 2d ed., 10 vols. (New York, 1958), vol. 8. In addition to these sources, see three useful volumes which are partly biographical: Lewis Masquerier, Sociology; or the Reconstruction of Society, Government, and Property (New York, 1877); Joshua King Ingalls, Reminiscences of an Octogenarian in the Fields of Industrial and Social Reform (New York, 1897); and Thomas Ainge Devyr's curious The Odd Book of the Nineteenth Century; or, "Chivalry" in Modern Days, a Personal Record of Reform-Chiefly Land Reform, for the Last Fifty Years (Greenpoint, N.Y., 1882). 
foreclosure for debt; the recognition of squatters' rights and a federal homestead law granting land to the landless; and land limitation that would prevent the accumulation of land (and property in general) in such amounts as would dispossess others in the society. Almost immediately, National Reformers became involved in what they saw as related activities, notably trade unions, cooperatives, "communitist" social experiments, womens' rights, and the antislavery movement.

The antebellum American Agrarians also established significant international ties. Regularly exchanging newspapers and ideas with the British Chartists, they even proposed an "Industrial Congress of the World" fourteen years before the organization of the International Workingmen's Association (IWA), the so-called First International. The German leaders of that future IWA, Karl Marx and Friedrich Engels, became familiar with the National Reformers through the Chartists and saw the Agrarians as growing from a "socialist and democratic tradition" both indigenous to the United States and analogous to their own Communist League. As if to confirm such a judgment, some surviving National Reformers, as old men, organized American sections of the IWA in the $1870 \mathrm{~s}^{6}$

Within the antebellum United States, however, the NRA became "national" only in a limited sense. It inspired no more than a handful of supporters in the slave states of the South. Indeed, the expansion of southern slavery, which posed a particular threat to the National Reformers' hopes for the country's future, came increasingly to preoccupy their public activities. As

6. The very issues of the English Red Republican which serialized the first English translation of the Communist Manifesto carried news about the development of National Reform in the United States. See the excerpts from Evans's paper in the Red Republican, 13 July 1850, 29, and the proceedings of the Industrial Congress held at Chicago, ibid., 9 November 1850, 163-64. For Marx and Engels's awareness of the American Agrarians, see The German Ideology, ed. R. Pascal (New York, 1939), 123; sections 2 and 4 of their Manifesto of the Communist Party, available in many editions and printings; and Engels's Principles of Communism, included in Dirk J. Struik, The Birth of the Communist Manifesto (New York, 1971), 188. See also Lewis S. Feuer, "The Alienated Americans and Their Influence on Marx and Engels," in his Marx and the Intellectuals: $A$ Set of Post-Ideological Essays (Garden City, N.Y., 1969), 164-216; Samuel Bernstein, The First International in America (New York, 1962); James C. Mohr, The Radical Republicans and Reform in New York during Reconstruction (Ithaca, N.Y., 1973); and David Montgomery, Beyond Equality: Labor and the Radical Republicans, 1862-1872, 2d ed. (Urbana, Ill,, 1981). 
a result, the NRA itself began to fade into the broader politics of "Free Soil," with the more radical Agrarians sustaining a coherent national organization only through a rather exotic secret society called the Brotherhood of the Union founded by George Lippard, a romantic socialist thinker and the country's leading Gothic novelist.?

These radical urban working-class people saw their plight as closely related to that of their fellow citizens living in rural areas. A major source of inspiration for their organization of the NRA had been the "Anti-Rent War" which broke out in 1839 among the tenant farmers of upstate New York. Also, the National Reformers themselves acted on an experience not confined to the neighborhoods of the lower east side of Manhattan. Evans himself, for example, became "firmly convinced, by eight years' experience as an agriculturalist, in addition to twelve (boy and man) as a mechanic, that neither description of labor is properly rewarded." He saw the hopes of a final victory for Agrarian measures in "the votes of the small farmers who were the majority and who would be benefitted by their adoption." Another National Reformer, active among the Anti-Renters, insisted that "any union of the laboring classes should embrace the Agriculturalists. ${ }^{78}$

The National Reformers faced serious obstacles in their efforts to convey their message to rural Americans "so widely and unnaturally scattered," and they acknowledged some initial opposition from "a quarter where we would, perhaps, least expect it," among "that large and sturdy class, the farmers of the North." Nevertheless, the Agrarian city dwellers pointed with pride to achievements like their upstate New York petition that bore the names of a hundred rural voters, including those of many of the wealthiest farmers in Genesee County. ${ }^{9}$

7. See Roger Butterfield, "George Lippard and His Secret Brotherhood," Pennsylvania Magazine of History and Biography 79 (July 1955), 285-301.

8. "To the Public," Workingman's Advocate, 16 March 1844. On the AntiRenters, see Henry Christman, Tin Horns and Calico: An Episode in the Emergence of American Democracy, 2d ed. (New York, 1961). Their organization of a "New York Farmers Club" was noted in Young America, 19 April 1845. The New England Protective Union, a cooperative movement launched by Fourierists active in the NRA, sought support from New York farmers. Voice of Industry, 17 December 1847.

9. Workingman's Advocate, 7 June, 6 July 1844; Proceedings of the Seventh 


\section{Voting Yourself a Farm}

The Agrarians saw particular opportunities where the constraining political, social, and economic norms they faced in the East had yet to be fully institutionalized. The constitution of the NRA had mandated its correspondence "with intelligent settlers in the new states and in the territories" and "editors near the western and northern frontier," particularly addressing "the farmers of the West." Joshua King Ingalls, an Agrarian visitor to the Midwest, discerned the basis of regional differences with the Northeast in "the dependence of the Western and Southern States on Eastern and European capitalists." Midwesterners, he argued, tended to be "more favorable to liberalism in all things." $\mathrm{H}$. H. Van Amringe, another NRA representative touring the region, warned of the particular threat of speculative capital. "Wherever the pioneer is found, there will be found the land speculator," he wrote. "The moment the hardy tiller of the soil settles down upon his few acres and commences an improvement, the adjoining acres are bought up by the speculator, who is able to hold on to his purchase until he can sell at prices much greater than the Government asks. His land rises in value in consequence of the improvements the few settlers have made." 10

In the West, argued Ingalls, the choice between standards that would be either "mutual or feudal and give the results of labor to the laborer or to a combination of landlords, depends in a great measure upon the early adoption of Land Reform principles." The eastern Agrarians eagerly followed the development of that decision, and as early as the spring of 1845 Evans began warning about land speculation in the distant lowa Territory. He even initiated a discussion within the New York City NRA of the possibilities of organizing a group of local working-class people to emigrate to the area. ${ }^{11}$

Annual Industrial Congress, held in Washington, D.C. (n.p., [1852]).

10. Workingman's Advocate, 30 March, 20 July 1844; Ingalls's report, in New York Daily Tribune, 15 June 1850; and "Freedom of the Public Lands," reprinted from the New York Globe, in Voice of Industry, 31 March 1848.

11. Ingalls report, New York Daily Tribune, 15 June 1850; "Land-Lord War in lowa," reprinted from St. Louis Reporter, and "Patroonery in Iowa," reprinted from Wisconsin Herald (Lancaster), in Young America, 12 April, 28 June 1845. For the model Agrarian township plans, see Workingman's Advocate, 18 June 1844, and the National Reform Almanac, for 1849 (New York, 1848), 35, 36. 
Adherents of National Reform organized themselves early in the history of Iowa. By early 1854 a writer to an eastern Agrarian journal, the Monthly Jubilee, reported from Fairfield that the movement had "taken root in this Valley of the Mississippi." Moreover, he added, they had engaged in their activities there for "a number of years past." 12

Although no record survives of an organized immigration by the NRA to the territory, individual land reformers did move there. In this newly settled area an eastern journeyman like Barlow Granger could launch a new career that included the exercise of public offices like city attorney, county judge, and mayor of both Des Moines and nearby Sevastopol. ${ }^{13}$ The son of a farmer and tavernkeeper in upstate New York, Granger had enjoyed a limited formal education in Rochester before, at the age of fourteen, entering the office of the Courtland Advocate as an apprentice. In 1835, at the age of nineteen, he finished his apprenticeship and set out with twelve cents in his pocket. For years he labored in printing offices in Hudson, Troy, and New York City. Periodically, he also worked his way north to New Haven, south to Charleston, South Carolina, and Columbus, Georgia, and west to Cleveland and Detroit. During these years he became a confirmed advocate of National Reform, probably under the influence of Horace Greeley's pro-Agrarian New York Tribune, where Granger had worked as a compositor.

Granger's migration to Iowa was a rather haphazard and solitary adventure. Leaving Albany in the spring of 1847 , he visited Chicago and crossed Wisconsin to the tiny trading post of St. Paul, Minnesota. He took a steamer down the Mississippi that fall and wintered in St. Louis, taking a job at the St. Louis Republican. Joined by a friend from Albany in 1848, he returned north with the warm weather to Keokuk and thence up the Des Moines River. He later remembered that their view of the river valley from the bluffs near Fort Des Moines convinced him to stay. After obtaining some land (what later became Pioneer

12. The letter from Fairfield is quoted in The Monthly Jubilee 4 (March 1854), 89, which also reprinted, on 90-94, his letter to Philadelphia's Ledger.

13. On Granger, see The History of Polk County, Iowa (Des Moines, 1880), 904; A Memorial and Biographical Record of Iowa (Chicago, 1896), 134-36. 
Park), Granger gained admission to the bar and, in 1849 , launched the Iowa Star.

Another Agrarian newspaperman who moved to lowa was William Haddock, a founder of the NRA. He spent several years in New York City, where, with John Windt, who had hosted the founding meetings of the NRA, he printed an Agrarian newspaper and a series of tracts that included a little volume of movement songs. Later, as an old man, Haddock recalled his move to Philadelphia in January 1850, and commented that such large cities, even at that early date, "had and could have only two classes, in the main, the employers and the wage earners." As one of the latter he had experienced "small chance of rising" and great frustration with his coworkers, who generally "took matters so tranquilly" that, as a group, they even lacked "the heart to get up a decent 'strike' as a protest against fate." Finally, in the spring of 1856 , Haddock took his family by train to Rock Island and thence into Iowa. They settled in Iowa City, where he, too, eventually gained admission to the bar, edited a paper, and raised troops during the Civil War, thus exercising some of the political influence denied him in the East. ${ }^{14}$

Other early settlers also had Agrarian credentials. Stephen Tabor of Independence was the brother-in-law of Lewis Masquerier, a leader of the NRA. Tabor's family had befriended Paine at the turn of the century in New York and had enjoyed the support of the NRA in earlier political campaigns in Massachusetts. James Vincent, a regular correspondent of Greeley's New York Tribune, joined other graduates of Oberlin College in colonizing the community of Tabor on the Missouri River; there he raised three sons-Henry, Cuthbert, and Leopold-who later became leading figures in the Populist movement in Kansas. ${ }^{15}$

14. On Haddock, see Workingman's Advocate, 24 July, 9 September 1844; Documentary History of American Industrial Society, 8: 27; Masquerier, Sociology, 104, 126; Ingalls, Reminiscences, 37; and Haddock, A Reminiscence: The Prairies of Iowa and Other Notes (Iowa City, 1901), 8, 9, 13, 14, 60-61.

15. On Tabor, see Masquerier, Sociology, 125, and Moncure F. Conway, The Life of Thomas Paine, ed. Hypatia B. Bonner (London, 1909), 314. On the Vincents, see McMath, Populist Vanguard, 114, and Goodwyn, The Populist Moment, 61-66. The town of Tabor, lowa, originated among colonists from Oberlin, Ohio. See James H. Fairchild, Oberlin: The Colony and the College, 
Significantly, though, Agrarianism in Iowa did not simply migrate to the state with eastern radicals. The settlement of the Midwest itself posed questions about the legitimacy of claims by homesteaders and squatters, issues not addressed by the political party divisions of the day. In at least thirty Iowa counties, residents organized associations to defend the legitimacy of their claims. Such associations did not, of course, reflect exclusively the interests of homesteaders and squatters in protection against the wiles of ruthless eastern speculators, for local men, too, sought to speculate in the vast tracts of unoccupied land and hoped to reap large profits through their sale to newcomers. Nevertheless, the presence of such organizations demonstrates that the practical circumstances of life and labor in early Iowa raised questions addressed by the principles of the NRA. ${ }^{16}$

Eager to encourage organization in the Midwest, the third annual session of the National Industrial Congress of land and labor reformers met in Philadelphia in June 1848 and placed on its executive committee William M. Stewart of Marion in Linn County. That same congress struggled to address the emergence of a Free Soil party dominated by disgruntled Democratic politicians willing to promote a homestead bill unencumbered by land limitation or guarantees against foreclosures. ${ }^{17}$ Drawn after 1848 into the new coalition politics of antislavery, in which others would set the tone and formulate policy, the NRA barely survived.

Nevertheless, the Agrarians sustained a national network through the Brotherhood of the Union, which rather quickly penetrated Iowa. By October 1850 its Supreme Circle assembled at Independence Hall in Philadelphia identified three Iowa circles, Nos. 117, 137, and 193. The last of these, at Fort Des Moines, grew under the leadership of Barlow Granger. ${ }^{18}$

1833-1883 (Oberlin, Ohio, 1883), 151-52, and Morton M. Rosenberg, Iowa on the Eve of Civil War: A Decade of Frontier Politics (Norman, Okla., 1972), 139.

16. Allan $G$. Bogue offers a valuable discussion of "The Iowa Claim Clubs: Symbols and Substance," in Vernon Carstensen, ed. The Public Lands: Studies in the History of the Public Domain (Madison, Wis., 1963), 47-70.

17. The National Reform Almanac, for 1849, 20.

18. The manuscript rolls of the Brotherhood of the Union are in the Brotherhood of America Papers. See also [John Bell Bouton], The Life and 
Some leaders of the Brotherhood who attended this national gathering in Philadelphia also attended an adjacent convention of German immigrants committed to land reform. By the fall of 1850 this Arbeiterbund, too, had gained a modest following in Iowa. Its founder, Wilhelm Weitling, a tailor who had been the mainstay of the Communist League in Europe, visited his cothinkers in the state, addressing a branch of the league at Dubuque. (English-speaking sympathizers in the area may have participated in a short-lived association of radical freethinkers sympathetic to the NRA, centered across the Mississippi in nearby Galena, Illinois, and active in 1849 and 1850.) Moreover, Iowa was the scene for the final collapse of this national organization of German advocates of a "republic of labor" when it became preoccupied with supporting a draining socialist "Communia" some six miles south of Elkader. ${ }^{19}$

Agrarians were particularly active. in several communities of southeastern Iowa. Circles of the Brotherhood of the Union functioned in Fort Madison and Bloomfield by the fall of 1850 . The following winter the Icarian community at Nauvoo, Illinois, watched with interest the ferment among "mechanics and laboring men" of Keokuk, encouraging them to organize cooperative groups. Fairfield became the center of activities for a group of Christian reformers sympathetic to National Reform and oper-

Choice Writings of George Lippard (New York, [185?]), 92, and David S. Reynolds, George Lippard (New York, 1982). In adjacent areas of Illinois, Fulton County had a Fourierist group at Canton and a circle of the Brotherhood at Bernadotte. Hancock County had a circle at Pontoosuc and the Icarian settlement at Nauvoo. The Brotherhood also had a group at Macomb in McDonough County. Robert S. Fogarty, Dictionary of American Communal and Utopian History (Westport, Conn., 1980), 191, 195; Workingman's Advocate, 20 July 1844; and Carl Wittke, The Utopian Communist: A Biography of Wilhelm Weitling (Baton Rouge, La., 1950), 176-78.

19. Wittke, Utopian Communist, 152, 175-76, 239-73; and Friederich Albert Sorge, "Die Arbeiterbewegung in der Vereingten Staaten," serialized in Die Neue Zeit 9, pts. 1-14, pt. 1 [1890-1895], translated by Brewster Chamberlin and Angela Chamberlin and published as Friedrich A. Sorge's "Labor Movement in the United States": A History of the American Working Class from Colonial Times to 1890, edited by Philip S. Foner and Brewster Chamberlin (Westport, Conn., 1977), 93. On Galena's organization, see Gilbert Vale's Independent Banner 1 (undated issues, 1849-1850), 133-36, 570-76. One participant in the Galena association, M. P. Silverburgh, had been in a pro-Agrarian reform group in Mineral Point, Wisconsin. Young America, 6 March 1847. 
ating under the leadership of a local man who was himself "wealthy... for this western country." 20 Much research must be done to define with clarity the impact of such groups on the course of agrarian protest, but the dynamic of National Reform is particularly evident in some of the small, face-to-face communities of the upper Midwest, of which Bloomfield, Iowa, is a significant example.

B

BLOOMFIELD and Davis County took form after the expiration of an Indian treaty in the spring of 1843 had opened the area to white settlers. Almost from the beginning, those settlers included people informed by the anticapitalism of such theorists as Robert Owen, Charles Fourier, and Etienne Cabet. Like other cothinkers of the NRA, however, the radical new residents of Davis County sought change not through the establishment of experimental communities (like Cabet's settlement across the Mississippi River from Fort Madison at Nauvoo, Illinois), but through political action.

By 1850 National Reformers at Bloomfield had formed Circle No. 117 of the Brotherhood of the Union, the first organized in the state. One of their number, John P. Wilkinson, represented Iowa in the national order's Supreme Circle. In the mid-1850s the national officers of the Brotherhood noted that Circle No. 137 at Fort Madison had collapsed; they did not make a similar notation about the group at Bloomfield, implying that the Bloomfield circle continued to function for some years after its formation. Although records of this secret society seldom recorded members' names, enough information survives on that circle to indicate its importance in the community. ${ }^{21}$

At least two of the three authors of the town's charter, Samuel G. McAchron and Horace A. Spencer, were members of the Brotherhood. Spencer, a New Hampshire-born blacksmith, probably found his Agrarianism in Iowa or at Mount Sterling, Illinois, where he had lived since 1838. McAchron, a lawyer active in local politics, won some elections, like that for the state senate in 1852, and lost others, like that of 1856 for delegate to the con-

20. See manuscript rolls of the Brotherhood of the Union; Nauvoo Popular Tribune, 15 February 1851; and Monthly Jubilee 4 (March 1854), 89-90.

21. See manuscript rolls of the Brotherhood of the Union, and Bouton, Life and Writings of George Lippard, 92. 
stitutional convention. Another member, James A. Songer, ran as a Republican for coroner in 1859. Still another member, William G. Ward, became the printer-editor of a series of local newspapers, including Ward's Own, The Iowa Flag, and, later, the Democratic Clarion. Dr. Calvin W. Phelps, another locally prominent figure, may have been involved with the circle at Fort Madison. ${ }^{22}$ Clearly, adherents of a radical Agrarianism helped to shape the political climate of the community.

One coworker of these men at the Davis County courthouse was Abram Weaver. Having taken his family from Ohio to Michigan, and to Keosauqua by the end of 1842 , Weaver had entered the area on the day it opened to white settlers, establishing a farm on the Chequest Creek near where the village of Belknap grew, four miles to the north of the future county seat. The family moved to Bloomfield in 1846 when he became the clerk of the district court. ${ }^{23}$ In such an environment, Weaver himself may have, at some point, stood before the altar of the Brotherhood to pledge his resistance to the "Lords of Labor."

The now forgotten Bloomfield Agrarians may have left a legacy in the career of Abram's son, James Baird Weaver, the future leader of the insurgents in the U.S. Congress and the presidential candidate of the Greenback-Labor party in 1880 and of the Peoples' party in 1892. After a modest education, the young Weaver worked as the mail carrier between Bloomfield and Fairfield, another center of Agrarian activities. At sixteen years of age, he hoped to accompany his brother-in-law, Dr. Phelps, to the newly discovered gold fields of California. Unable to do so, he entered McAchran's office and began reading law there in the summer of $1852 .{ }^{24}$ During this period

22. History of Davis County, Iowa (Des Moines, 1882), 445-50, 493, 494, 570, 571, 635-36. Dr. Phelps, too, ran for public office as a Republican. Ward seems to have resisted the drift away from the Democrats, taking up the editorship of the local Democratic Clarion in 1861. The only known member of the Fort Madison circle is given as "W. W. Phelps," but local references give no indication that an individual with such a name lived there, the nearest being that of $C$. W. Phelps. "W.W. Phelps" may have been miscopied from a manuscript source into Bouton, Life and Writings of George Lippard, 92, and might refer to Weaver's brother-in-law. A Mormon printer named W. W. Phelps, however, had worked in Missouri during the 1830 s and may have been on the fringes of the church's move to Nauvoo, across the river from Fort Madison. The WPA Guide to 1930s Missouri (Lawrence, Kans., 1986), 107, 387.

23. Fred Emory Haynes, James Baird Weaver (lowa City, 1919), 1, 2-3.

24. Ibid., 8-11. 
of his life, when Weaver first developed his taste for politics and the law, it is scarcely conceivable that he did not get something of a political as well as a legal education under the tutelage of a locally prominent land reformer.

The next year brought Weaver an opportunity to see the political potential of Agrarianism. In March 1853 Dr. Phelps took him and two others on another overland trek to California, arriving on August 15 in Sacramento, the site of an armed "Squatters' Riot" only three years earlier. Throughout the decade, an Agrarian-led Settlers' League based in Sacramento and San Francisco and oriented, at the time, towards the Democratic party, continued to battle against the acceptance by American authorities of large land grants often backed by fraudulent titles alleged to have been granted by the Mexican administrators just prior to the U.S. occupation. The squatters also waged a stubborn and massive resistance to the development of a "land monopoly" in the state, at times with arms in hand. Weaver and Phelps visited both cities before returning by way of Panama. ${ }^{25}$

Weaver returned from the West with an interest in politics and launched a career in which his orientation shifted with that of National Reform. Beginning with a certain affinity for the antimonopolist rhetoric of the Jacksonian Democrats, he also embraced concerns that would draw him towards the emerging new movement to bar slavery from the territories. In 1857 he publicly turned to the new Republican party. ${ }^{26}$ Then, after his service in the Civil War, the booming development of the American economy and its industrial order, which provided Republican leaders with an exclusive measure of the nation's wellbeing, forced Weaver's reappraisal of his partisan loyalties.

25. Ibid., 10. Paul W. Gates described conditions there in several essays: "California's Embattled Settlers," California Historical Society Quarterly 41 (June 1962), 99-130; "Pre-Henry George Land Warfare in California," ibid. 46 June 1967), 121-48; "The California Land Act of 1851," ibid. 50 (December 1971), 395-430; and "The Adjudication of Spanish-Mexican Land Claims in California," Huntington Library Quarterly 21 (May 1958), 213-36. The Overland Monthly carried two important pieces on the Sacramento squatters: D. B. Stillman, "Selling the Golden Fleece, III, 'War and Rumors of Wars," 1st ser., 11 (November 1873); and Josiah Royce, "The Squatter Riot of '50 in Sacramento: Its Causes and Its Significance," 2d ser., 6 (September 1885).

26. Haynes, Weaver, 11, 12-14, 18-19, 20. 
Old American ideals inspired Weaver's subsequent career as one of the most prominent national figures in the farm protests and agrarian insurgencies of the late nineteenth century. His later biographer, Fred Haynes, found an important source of Weaver's politics in a "deep respect for his father, who was both farmer and mechanic." That early experience, Haynes concluded, formed an "interest in and sympathy with both farmers and artisans that had much to do with the shaping of his career." Weaver himself later recalled that only "after consultation with my parents" did he publicly embrace the Republican party. The most likely influences beyond his immediate family were Bloomfield's Agrarians, men like McAchron, Spencer, Songer, Ward, and the other local members of the Brotherhood of the Union. In 1876 Weaver helped to launch the local "Cooper and Cary Club" to promote the Greenback ticket of Peter Cooper and Samuel Cary. Appropriately, they founded the organization in the blacksmith shop of Captain Spencer, the sixty-three-yearold Agrarian radical. ${ }^{27}$ Having spent his political adolescence among such men, Weaver embarked on a career of articulating ideas and values largely reminiscent of theirs. Other prominent leaders of the postwar upheaval may have had similar influences in their background.

HISTORICAL LTTERATURE on the late nineteenth-century agrarian upheaval portrays small farmers with values rooted in the pastoral past developing identity as a group besieged and politicized by the rising tide of industrialism. The prehistory of that upsurge offers other valid insights. The shadow of corporate dominance that so threatened the independent middle class of small farmers in the postwar Midwest had loomed perceptibly on the horizon for decades. In anticipation, some midwesterners prepared to meet the challenge through Agrarian measures that would forestall or even eliminate the development of monopolism. Fears that the monopoly of western lands would fuel the development of corporate power had moved the National Reformers to promote the emerging coalition politics of the Free Soil, and, later, Republican parties. But the antebellum plantation economy of the South had never been the only form of land

27. History of Davis County, 685; Haynes, Third Party Movements, 156. 
monopoly; the antebellum Agrarians clearly anticipated the postwar challenges to Republican hegemony in states like lowa by a succession of popular third party efforts. One of the most important founders of the Patrons of Husbandry - the Grange movement which swept across the Midwest in the early 1870swas Daniel A. Robertson, an Ohio National Reformer who had moved to Minnesota in $1852 .{ }^{28}$ So, too, veteran Agrarians, alongside the younger radicals they influenced, played a role in the postwar electoral mobilization of the discontented.

As the case of Davis County hints, more detailed research into the local development of Agrarian activism may reveal, in some quarters, a significant and astonishing level of continuity and persistence over many years. This historic continuity enabled Americans discontented with the bipartisan silence of Republicans and Democrats on the industrial and corporate transformation of postwar American life to recall the earlier bipartisan evasion of the slavery issue by Democrats and Whigs; many, after all, had experienced the process whereby the introduction of such an issue, unaddressed by the prevailing political parties, could completely redefine American politics. ${ }^{29}$ Some may have seen their efforts as leading to a new political party, while others hoped that it might force a general realignment similar to that they had witnessed in the 1850s. To see Greenbackism and Populism simply as short-lived and pragmatic reflexes, then, would be to understate the legitimacy and authenticity of their ideas and strategies.

So, too, Agrarianism had a vital, even formative, urban and working-class dimension. While articulating issues of broad concern, antebellum Agrarianism originated as an organized movement in the seaboard cities among politicized working-

28. In general, see Solon J. Buck, The Granger Movement: A Study of Agricultural Organization and Its Political, Economic, and Social Manifestations, 1870-1880 (Cambridge, Mass., 1913). On Robertson, see J. Fletcher Williams, A History of the City of Saint Paul, and of the County of Ramsey, Minnesota (St. Paul, 1876), 283-84, 286-87, 391, 402, 412-13. See, too, the account by "S. Weaver" of developments at Muscatine in the publication of the revived Brotherhood of the Union, The White Banner, 1 November 1874.

29. The political careers of, among others, Galusha A. Grow, George Washington Julian, Joshua R. Giddings, and Benjamin Franklin Wade grew from the juncture of Agrarian and antislavery reform. For a discussion of this overlap from "the top down," see Eric Foner, Free Soil, Free Labor, Free Men: The Ideology of the Republican Party before the Civil War (New York, 1970). 
class people. Farmers, artisans, and small-town professionals in many communities scattered across the North responded by forming local affiliates. The postwar industrialization that shattered the security of many small farmers also overwhelmed small-scale artisans and thwarted the aspirations of those citizens who lacked any productive property, depending instead on wages for a living. Inspired by the old National Reform vision of an America in which economic as well as political power would be widely and democratically distributed through the society, large numbers of Americans in the late nineteenth century rejected politics generated by the concerns of large business interests and raised the old Agrarian standard of a new political alliance of farmers, laborers, and individual professionals to promote the interests of "the people."

Finally, recognition of the antebellum and working-class dimensions of the Agrarian upheaval underscores one of its most essential, if neglected, features: its radicalism. The evolving needs of politically empowered elites led Progressives and New Dealers to adopt concepts formulated by the earlier Agrarians, including the centrality of government action in certain areas of the nation's economy and such reforms as paper money, the income tax, woman suffrage, and the direct election of U.S. Senators. However, the original proponents of such measures did not see their efforts as part of the political reorganization of twentieth-century corporate capitalism. Quite the contrary. Their reforms were components of another, Agrarian program that more generally posed deeply rooted and often discomforting insights into the nature of political power in a society where wealth is polarized.

That these insights do not currently have a coherent political expression in the United States has influenced our perception of Agrarianism as somewhat of a sideshow to the postwar rise of modern monopoly capital, as an episodic series of pragmatic outbursts by farmers that ultimately found effective expression in the emergence of a modern pluralistic corporate state. Yet, as the prehistory of Agrarian radicalism in Iowa indicates, ideas not readily apparent may not be as uprooted or completely defeated as they seem. If so, a broader public now largely disaffected with its electoral options may again turn to the fundamental insights of the old Agrarians, and in the process, per- 
The ANNALS OF Iowa

haps, encourage a scholarly rediscovery of the persistent movement of otherwise obscure citizens who, through so much of American history, have promoted farmer-labor solidarity and the goal of a radically more democratic nation. 
Copyright of Annals of Iowa is the property of State of Iowa, by \& through the State Historical Society of Iowa and its content may not be copied or emailed to multiple sites or posted to a listserv without the copyright holder's express written permission. However, users may print, download, or email articles for individual use. 